UDC 339

DOI 10.33111/iep.eng.2021.34.06

\title{
The United Nations Industrial Development Organization's Role in Modern Industrialization of Nigeria
}

\author{
Salisu OJonemi Paul ${ }^{1}$, \\ Chikelue Ofuebe ${ }^{2}$
}

\begin{abstract}
The high rate of economic growth, the provision of basic facilities, and job creation are products of any nation's level of industrialisation. Globally, no nation is considered to have attained a concerted level of a high standard of living in the absence of economic development that is highly productive-based. However, Nigerian industrialisation has continued on a downward journey in the 21st century, despite several industrial development policies. Therefore, this paper is an attempt to find out how industries have fared and challenges facing their development in Nigeria. It is also an effort to unearth whether UNIDO has influenced Nigeria industrial development. The study adopted a descriptive research design and documentary data analysis method to elucidate the fact that the UNIDO supports have not significantly impacted industrialisation in Nigeria. The adoption of Top-Down as a theoretical model of analyses has validated the fundamental issues raised that; several industrial development programmes and projects initiated by successive administrations in Nigeria to help in revitalizing the country's industrial landscape in line with the government's goal of emerging among the top 20 most developed economies in the world by 2020 have failed. The major informed findings of the paper are that for the time being, Nigeria still remains a consuming economy of finished products including some raw materials and not a producing one. In addition, her critical construction and maintenance engineering activities are foreign experts-based thereby relegating the local content to the background. These cumulatively result in the advancement of the fact that the UNIDO supports have not significantly impacted the development of industries in Nigeria. The discourse conclusively recommended the creation of a robust support programmes for Small and Mediumsize Enterprises (SMEs) being major channels of entrepreneurship development, innovation and socio-economic sustainability; the development of investment and technological promotion environment, improvement of industrial domination, official and regulatory framework, data and critical infrastructure; and the establishments and support for a wide-range business-oriented institutions and organisations for the provision of collective and targeted services for other enterprises in traditional sectors like food, textiles, wood, leather, and agro-mechanism), including intensive economic segments like electronics and biotechnology.
\end{abstract}

KEY WORDS: challenges, economy, implementation, industrial development, international organization, policy.

\section{Introduction}

Socio-economic and national development through industrialisation has undoubtedly become a key issue in any international relations discourse. Ever since the end of the Cold War, some researchers and international players

\footnotetext{
${ }^{1}$ Paul Salisu Ojonemi - Doctoral Degree Student at the Department of Public Administration and Local Government Studies, Faculty of Social Sciences, University of Nigeria, Nsukka (Nigeria). Sphere of scientific interest: industrial development, policy studies. E-mail: salisunelson@gmail.com

2 Ofuebe Chikelue - Ph.D., Professor at the Department of Public Administration and Local Government Studies, Faculty of Social Sciences, University of Nigeria, Nsukka (Nigeria). Sphere of scientific interest: governance, administration, political science. E-mail: chike.ofuebe@unn.edu.ng
}

IEP, No. 34 (2021), pp. 115-138

(C) Salisu Ojonemi Paul, Chikelue Ofuebe, 2021 «All rights reserved»

ISSN 1811-9832/2021/No. 1 (34) 
have identified essential characteristics of modern international relations as the growing predisposition of nation-states to embark on one form of economic collaboration and international diplomatic relationships ${ }^{3,4,5}$. This brought the institutionalisation of a traditional form of economic control and industrial development ${ }^{6}$. This could be identified as one of the brains behind the emergence of major economic and industrial development programmes which led to neo-liberalism and industrialisation to mainly cater for food security, employment, income generation, resource conservation and environmental protection which have emerged as global concerns ${ }^{7,8}$. Therefore, since the emergence of the industrial revolution in England in over two centuries ago, industrialisation has conceivably impacted both socio-economic and political development of the world than any multifarious factor that can be imagined ${ }^{9}$.

Consequently, the most identified dynamic driver of collective wellbeing and prosperity of any nation is industrialisation. It can be observed that no country has ever attained a standardised socio-economic development without an advanced and developed industrial sector. To this end, it is emphasised that in order to confirm an unbiased distribution of the economic benefits of industrialisation, a strong commitment was made by the UNIDO "to address the multidimensional causes of poverty, through creating shared prosperity, advancing economic competitiveness, and safeguarding the environment." This is vital due to the fact that:

The importance of industrial development for sustainable development was explicitly recognised by the United Nations General Assembly in their proposition concerning the Sustainable Development Goals (SDGs), which includes inclusive and sustainable industrialization as SDG-9, along with fostering innovation and building resilient infrastructure ${ }^{10}$.

It is then conceived that during the 2013-2014 period, African States members of UNIDO have been assisted with programmes and projects that

\footnotetext{
${ }^{3}$ Onah, Roseline, and Jide Ibietan. "Democratic Stability and Regional Economic Integration: The Economic Community of West African States (ECOWAS) Experience." Nigerian Journal of Public Administration and Local Government 14, no. 1 (2009): 17-32.

4 T. Makinde, "Essence of bilateral relations in modern diplomacy," (2014), Retrieved from http://media4rural.blogspot.com.ng on 27/3/2018.

${ }^{5}$ D. Klavins, "Cultural diplomacy and international relations: New actors; new initiatives; new targets. The ICD Annual Academic Conference on Cultural Diplomacy December, (2015), $15^{\text {th }}-18^{\text {th }}$.

${ }^{6}$ Obwona, Marios, Isaac Shinyekwa, Julius Kiiza, and Eria Hisali. The evolution of industry in Uganda. No. 2014/021. WIDER Working Paper, 2014.

Harris, Jonathan M. "Basic principles of sustainable development." Dimensions of Sustainable Development (2000): 21-41.

${ }^{8}$ Cheng, S. K., Q. W. Min, and L. F. Li. "Research and theories in sustainable development in china, "Social and Economic Development-Volume VIII (2010): 208. Retrieved from http://www.eolss.net/Sample-Chapters/C16/E154-44.pdf, on 10/4/18

9 Encyclopedia of Sociology, "Dictionary definition of Industrialization in Less Developed Countries.” (2011). Retrieved from encyclopedia.com, free online dictionary on 23/3/18.

${ }^{10} \mathrm{UNIDO}$, "Inclusive and sustainable industrial development in Africa Region," (2015), Vienna-Austria: Vienna International Centre.
} 
will enable them to achieve the organisation's effort priority areas which include agro-business and "rural entrepreneurship, industrial policy development, trade capacity building, energy, youth employment, investment promotion, institutional capacity development, and energy efficiency, and climate change." Thus, amongst the countries in West African sub-region and sub-Sahara, Nigeria is one of the most industrialised nations ${ }^{11}$. He further noted that despite the fact that some studies have concentrated efforts on the manufacturing sectoral activities within the country, many of these researches have extensively stressed on some aspects of manufacturing especially at the regional level, small-scale industries and local crafts.

This paper will find out UNIDO and Industrialisation in Asia and Africa, origin, situation and challenges facing industries in Nigeria in the $21^{\text {st }}$ century, the impact of UNIDO support, and the possible ways that can make UNIDO stimulates industrial development programmes' implementation in Nigeria.

\section{Genesis and challenges of industrialisation in Nigeria}

Sectoral changes in the alignment of commerce and industry found a centre-piece "in the structural transformation that accompanies economic development." 12 There are some inherent relative factors-policy administration and technology which have been seen to determine various patterns of economic activities across countries. Particularly, the history of industrial development in Nigeria to entails substantial craft works in the early stages that metamorphosed into large-scale manufacturing over the years. ${ }^{13,14}$ Thus, Nigeria embraced the factory type industrialisation as the major remedial measure to the challenge of her underdevelopment following the coming of Europeans. This specifically occurred in the wake-up of formal trade contact which brought about the first widely recognised forms of current industrial growth. ${ }^{15,16,17}$

${ }^{11}$ Dankumo, A., Joshua Sunday Riti, and Bashir Saka Ayeni. "Contribution of Agricultural and Industrial Sectors to the Development of Nigerian Economy from 1995 to 2012." International Journal of Business, Management and Allied Science 2 (2015): 2128-2135.

12 Mayer, Jörg. Industrialization in developing countries: some evidence from a new economic geography perspective. No. 174: 1 - 37. United Nations Conference on Trade and Development, 2004.

${ }^{13}$ Ajayi, Dare Dickson. "Recent trends and patterns in Nigeria's industrial development." Africa Development 32 no. 2 (2007): 139-155.

${ }^{14}$ Olayiwola, Adewale Mukhtar, and Michael Oluwabukunmi Lawal. "Mapping urban growth and its impact on agricultural lands in Abeokuta, Nigeria: 1966-2016." Interdisciplinary Environmental Review 19, no. 3-4 (2018) $289-305$.

15 Onyemelukwe, J. O. C. "Structural and locational characteristics of manufacturing" In J. S. Oguntoyinbo, O., O. Areola \& M. Filani, (eds.), A Geography of Nigerian Development, $2^{\text {nd }}$ edition. Ibadan: Heinemann Educational Books Ltd, (1983): pp. 296-310.

16 Calhoun, Craig, Georgi Derluguian, and Georgi M. Derluguian, eds. The deepening crisis: governance challenges after neoliberalism. NYU Press, 2011.

17 Tignor, Robert L. Capitalism and nationalism at the end of empire: state and business in decolonizing Egypt, Nigeria, and Kenya, 1945-1963. Princeton University Press, 2015. 
There is differing view on how developing states particularly the ones in sub-Sahara Africa are incorporated in global economies. This emanated from "the dramatic rise in world oil prices in 1974 [leading] to a sudden flood of wealth that can be described as dynamic chaos because, much of the revenue which was intended for investment to diversify the economy, also spurred inflation and, coming in the midst of widespread unemployment, underscored inequities in distribution." 18 As a consequence, successive governments in Nigeria launched several socio-economic development programmes that ranges from $1^{\text {st }}, 2^{\text {nd }}, 3^{\text {rd }}$, and $4^{\text {th }}$ National Development Plans $(1962-1968$; 1970-1974; 1975-1980; 1981-1985) to the three Rolling Plans (1990-1992; 1993-1995; 1996-1998) respectively. ${ }^{19,20,21,22,23}$ The country also initiated the 2010 and 20:2020 Vision, and the National Economic Empowerment and Development Strategy (NEEDS). However, Nigeria Federal Office of Statistics revealed that poverty has been massive, pervasive, and engulf a large proportion of the Nigerian society. ${ }^{24}$

Following these developments, the need for economic development strategy that will strengthen citizens against poverty, resulted in the emergence of industrialisation in Nigeria. The table 1 below shows the profiles of ten individuals who are well known to be pioneer industrialists in Nigeria.

Furthermore, the table 1 above noted the indication that indigenous companies had begun to move into capital and skill-intensive related to industrialisation. The development emerged in the pre-independence Nigeria and gathered momentum in the 1950s and post-independence with the establishment of Gramophone records in 1963 at Onitsha and Plastic foam in 1972 at Lagos. Consequently, the central position of industrialisation to national economic development as a pivotal force that led to the creation of a number of policies targeted at making Nigeria an industrialised nation. ${ }^{25}$ The first industrial approach in Nigeria was aimed at reducing over-dependence on foreign goods and save foreign exchange through the encouragement of manufacturing of goods that were previously imported. This effort by the federal government of Nigeria led to the promulgation of an Indigenisation Decree in 1972 -the fore-runner of Nigerian

\footnotetext{
${ }^{18}$ Metz, Helen Chapin, ed. Nigeria: A country study. Federal Research Division, 1991.

${ }^{19}$ Onah, Fab O. Managing Public Programmes and Projects. Great Ap Express Publishers Limited, 2006.

20 Anger, Barnes. "Poverty eradication, millennium development goals and sustainable development in Nigeria." Journal of sustainable development 3, no. 4 (2010): 138-144.

21 Jiboye, Adesoji David. "Urbanization challenges and housing delivery in Nigeria: The need for an effective Policy framework for Sustainable Development." International Review of Social Sciences and Humanities 2, no. 1 (2011): 176-185.

${ }^{22}$ Asaju, Kayode. "Industrialization: The Key to Nigerian's Developmental Questions." American Journal of Social Sciences 3, no. 3 (2015): 62-68.

23 NBS, Nigerian manufacturing sector summary report: 2010-2012. (2015). Retrieved from https://www.proshareng.com/newson 5/9/18.

${ }^{24}$ Oshewolo, Segun. "Galloping poverty in Nigeria: an appraisal of government interventionist policies." Journal of Sustainable Development in Africa 12, no. 6 (2010): 264-274.

${ }_{25} \mathrm{Agba}, \mathrm{A} . \mathrm{M}$. O., and Emmanuel Odu. "Globalization and the challenge of industrialization in developing nations: The Nigeria experience." IOSR Journal of Humanities and Social Science 12, no. 4 (2013): 41-47.
} 
Enterprises Promotion Decrees, that blocked foreigners from investing in certain enterprises and reserved involvement in specified trades to Nigerians. It was meant to support local industries and build prospects for Nigerian investors to take charge of the manufacturing sector of the country's economy. ${ }^{26}$ Large scale industrialisation in Nigeria was born through the Intercontinental Textile Industry, Atlantic Textile Mill, Lagos, Ajaokuta Steel Company Limited (ASCOL), The Dunlop Nigeria Plc., Michelin, and many other companies in the industrial sub-sectors. Large amount of industrialisation is paramount due to:

...the process of transformational changes of the human society socially and economically from an agrarian society into an industrial one. It involves vast economic and social changes such as a tendency to urbanization, a growing body of wage earners and increased technical and advanced education. Industrialization is the extensive organization of an economy for the purpose of manufacturing. ${ }^{27}$

Table 1

PROFILE OF EARLY INDUSTRIES AND INDUSTRIALISTS ${ }^{28}$

\begin{tabular}{|c|l|c|l|l|}
\hline S/No & \multicolumn{1}{|c|}{ Names } & $\begin{array}{c}\text { Date of } \\
\text { Establishment }\end{array}$ & \multicolumn{1}{|c|}{ Location } & \multicolumn{1}{|c|}{ Industry } \\
\hline 1. & T.A. Odutola & 1950 & $\begin{array}{l}\text { Ijebu-Ode, Ibadan, } \\
\text { Kano, Onitsha }\end{array}$ & $\begin{array}{l}\text { Tyre retreading, } \\
\text { plantations, tyres, } \\
\text { biscuits, brewery }\end{array}$ \\
\hline 2. & M. Ugochukwu & 1958 & $\begin{array}{l}\text { Lagos, Port } \\
\text { Harcourt, Onitsha, } \\
\text { Kaduna, Umeze }\end{array}$ & $\begin{array}{l}\text { Tyre retreading, saw } \\
\text { milling, foam, biscuits }\end{array}$ \\
\hline 3. & C.T.Onyekwelu & 1963 & Onitsha & Gramophone records \\
\hline 4. & J. Ade Tuyo & 1955 & Lagos & Bakery \\
\hline 5. & S.I. Fawehinmi & 1953 & Lagos & $\begin{array}{l}\text { Furniture, saw } \\
\text { milling }\end{array}$ \\
\hline 6. & J.K. Ladipo & 1938 & Lagos & Food processing \\
\hline 7. & B.E. Tejuoso & 1972 & Lagos & Plastic foam \\
\hline 8. & L. Omole & 1950 & Ilesha & Brewery \\
\hline 9. & $\begin{array}{l}\text { S.O. } \\
\text { Gbadamosi }\end{array}$ & 1937 & Lagos & Singlets, ceramics \\
\hline 10. & $\begin{array}{l}\text { F.S. Okotie- } \\
\text { Eboh }\end{array}$ & 1958 & Lagos, Sapele & $\begin{array}{l}\text { Rubber crepe, shoes, } \\
\text { cement }\end{array}$ \\
\hline
\end{tabular}

${ }^{26}$ Asaju, Kayode. "Industrialization: The Key to Nigerian's Developmental Questions." American Journal of Social Sciences 3, no. 3 (2015): 62-68.

${ }^{27}$ Mgbemene, Chigbo A., Chidozie C. Nnaji, and Chekwubechukwu Nwozor. "Industrialization and its backlash: focus on climate change and its consequences." Journal of Environmental Science and Technology 9, no. 4 (2016): 301-316.

${ }^{28}$ Forrest, Tom, and Tom G. Forrest. The advance of African capital: The growth of Nigerian private enterprise. University of Virginia Press, 1994. 
Therefore, the emerging economies have recognised industrialisation as a basic essential for socio-economic transition and transformation. ${ }^{29}$ From the foregoing, it is often paramount for new states to provide the factors needed for an industrialized society because, the substitution of manual tools by engines and power tools is the sine qua non of any developed economy.

From the foregoing, the importance of industrialisation is likened to public project that serves as a critical tool for accelerating successful development by the way it is described and emphasized. ${ }^{30}$ This made the operationalisation of any development framework to greatly depend on some variables which are found wanting in Nigeria. Politics, social and macroeconomic stability are placed as conditions for sustainable economic and industrial growth through a well-functioning institution rule of law, and the distribution of power within the country. ${ }^{31,32,33}$ Nigeria's manufacturing sector as the type that has been plagued by a myriad of challenges, most of which predate the $21^{\text {st }}$ century. ${ }^{34}$ It further identified these challenges to include "poor power supply, high cost of inputs and of doing business, multiple taxation, infrastructural deficit, low access to finance, institutional problems with intellectual and property rights, insecurity, low quality of 'Made in Nigeria' goods, poor information flow, and Lack of synergy between the educational system and the labour market." This statement that "800 industries have crumpled from 2009-2011, and 272 firms were also closed in 2016 along $20 \%$ capacity operation due to difficult and unstable operating business environment." 35,36

As a corollary, Nigeria is seriously handicapped by the dearth of skilled labour, lack of data, good transportation facilities, confused land laws that have complicated the securing of land for factory construction. Also, one amongst the major challenges of industrialisation in the Third World is the prevalent predisposition to still believe that any approach or method originating in the developed world must be 'better' than anything designed to or produced locally.

\footnotetext{
${ }^{29}$ Ikpe, Eka. "The Enduring Relevance of the Developmental State Paradigm Across Space and Time: Lessons for Africa on Structural Transformation and Agriculture in Oil-Rich Contexts." Journal of Asian and African Studies 53, no. 5 (2018): 764-781. Accessed from https://doi.org/10.1177/0021909617722375 on 10/2/18

${ }^{30}$ Kerzner, Harold. Project management: a systems approach to planning, scheduling, and controlling. John Wiley \& Sons, 2017.

${ }^{1}$ Kaplinsky, Raphael. "India's industrial development: an interpretative survey." World Development 25, no. 5 (1997): 681-694.

${ }^{32}$ Sachs, Jeffrey. The end of poverty: How we can make it happen in our lifetime. Penguin UK, 2005.

33 Mirakhor, Abbas, and Hossein Askari. "Institutional Structure of a Sound Economy." In Ideal Islamic Economy, pp. 119-137. Palgrave Macmillan, New York, 2017.

${ }^{34}$ FGN, Public Service Reforms in Nigeria 1999-2014 A comprehensive review. Abuja: The Presidency, 2015.

${ }^{35}$ NACCIMA, 800 companies shut down in 3 years. The Premium Times, September, 2012, 11. Retrieved from https://www.premiumtimesng.com/businesson 9/8/18.

36 MAN, Nigerian manufacturers lament. Premium Times, January, 2018, 10. Accessed from https://www.premiumtimesng.comon 13/9/2018.
} 
Furthermore, there is the syndrome of delay and abandonment of industrial development projects. There are the "age-old constraints of [failed] previous industrial policies, and addressing the underlying factors that have held back manufacturing in Nigeria for decades such as, industrial infrastructure, affordable finance, industrial skills, investment climate, standards, innovation, and local patronage" ${ }^{37}$. The commonest cause of delays and cancellation of industrial development projects and programmes in developing countries, Africa at large and Nigeria in particular is shortage and mismanagement of funds. For example, the government of Nigeria had spent over \$10bn on the Ajaokuta and Delta Steel Companies, Ovian-Aladja in the last 35 years with empty results. ${ }^{38}$ The integrated plants were envisaged to have multiplier effects on all sectors of the Nigerian economy including manufacturing, education, construction, transportation, and agricultural sectors, among others ${ }^{39}$.

Also, the source and nature of financing strongly influence project implementation with a high percentage of local equity, as in South Korea, rarely suffer project disruption ${ }^{40}$. The far-reaching "infrastructures normally required to support industrialisation in Nigeria contribute significantly to the total costs, and few countries can make the investment without securing loans" 41,42 . Succinctly:

Ajaokuta Steel Company Limited in Kogi State Nigeria, the second largest in Africa and 12th largest iron ore in the world has not only been under lock and key, but has remained a big centre for massive looting and wastage of the nation's resources...Russian company had to abandon the project in 1994 because Nigeria fell short of its contractual agreement by not releasing funds needed for the completion of the steel company ${ }^{43}$

To this end industrial development demands a high level of skill, technical and organisational know-how, and systemic complexity (supply of capital goods and technical services). Therefore, poor financing, huge capital requirements, and qualitative partnerships have constituted into fundamental challenges of industrialisation in Nigeria. There is absence of capital accumulation, capacity and physical development, and applicable critical infrastructures which enhance productive activities have surfaced as hurdles

\footnotetext{
${ }^{37}$ FGN, Public Service Reforms in Nigeria 1999-2014: A comprehensive review. Abuja: The Presidency, 2015.

${ }^{38}$ Bawa-Bwari, A. FG spent \$10bn on Ajaokuta Steel Company. The Punch Newspaper, August, $2016,19$.

${ }^{39}$ Oluyole, F. Ajaokuta: How Nigeria's largest industrial project failed. Premium Times Daily News, December, (2017), 26.

${ }^{40}$ Oyeyinka, Oyebanji, and Oluwole Adeloye. "Technological change and project execution in a developing country: evolution of Ajaokuta Steel Plant in Nigeria." Manuscript report/IDRC; 187e (1988).

${ }^{41}$ Olaoye, O. A. "Potentials of the agro industry towards achieving food security in Nigeria and Other SubSaharan African Countries." Journal of Food Security 2, no. 1 (2014): 33-41.

${ }^{42}$ N. Akpoti, Ajaokuta Steel Company, House of Reps and the acquisition plot. The Sahara Reporters, New York. March 26, (2018).

${ }^{43}$ S. George, Uses and abuses of Africa debt. In A. Adedeji (ed.), Africa within the world-beyond dispossession and dependence. London: Zed Books, 1999.
} 
to Nigerian industrial development. The only aspect of car manufacturing is assembling done by the Peugeot Assembly of Nigeria (PAN) in Kaduna before the year 2000. Furthermore, there is:

i. the manipulation of debts and enforcement of policies that cheapen the value of raw materials,

ii. little attention given to the emerging pattern despite the changing phases of manufacturing and industrial development policies,

iii. absence of heavy industries and car manufacturing has militated against effective transfer of technology, and

iv. Overall little level of inter-industrial networks ${ }^{44,45,46}$.

Another important factor worthy of mentioning is imbalance trade policy actions put in place by advanced nations to reduce access to importation of high-value machines for developing countries ${ }^{47}$. Similarly, Nigerian industries import machineries by purchasing with foreign currencies contrary to obtaining them partially or wholly as done by most developed nations.

\section{The UNIDO and Industrialisation in Asia and Africa: A Cross-National Comparison}

It is observed that there was significant change after the Second World War particularly 1960s on the assumption that national economic development is characterised by industrialisation, modernised agriculture and critical infrastructure. It is therefore worthy of note that there is no particular nation in the world which can boast to have attained a high level of socio-economic development in absence of an advanced industrial sector. However, China embraced a strategy of development that put the nation in a purposeful economic isolation, industrialisation and dominance. ${ }^{48,49}$ They noted that the country became conscious of her underdevelopment in comparison to Western countries which however made it to commence the reformation of her centrally planned and closed economy in 1978. Comparatively, Cambodia, Tunisia and Vietnam moved in one direction around foreign direct investment and exports - and sub-Saharan African countries like Angola, Ghana, Kenya, Mozambique, Nigeria, Sierra Leone,

\footnotetext{
44 Onimode, Bade. "Unequal Exchange, External Debt and Capacity for Development-Oriented Policies in African Countries." Development Thought, Policy Advice and Economic Development in Africa in the 20th Century: Lessons for the 21st Century: Ibadan: Ibadan (2003): 39-56.

45 Dankumo, A., JOSHUA SUNDAY Riti, and BASHIR SAKA Ayeni. "Contribution of Agricultural and Industrial Sectors to the Development of Nigerian Economy from 1995 to 2012." International Journal of Business, Management and Allied Science 2 (2015): 2128-2135.

${ }^{46}$ Kwanashe, J. D. Sustainable Development Goals: Where is the stand of Africa? Ghanaian Journal of Social Development of Development Research, 3 no 1 (2016): 35-51.

${ }_{47}$ Bijan, Zheng. "China's peaceful rise to great-power status." Foreign Affairs. 84 (2005): 18.

${ }^{48}$ Kniivilä, Matleena. "Industrial development and economic growth: Implications for poverty reduction and income inequality." Industrial development for the 21st century: Sustainable development perspectives 1 , no. 3 (2007): 295-333.

49 Toffler, A. Revolutionary wealth. New Perspectives Quarterly, 30 no 4 (2013): 122-130.
} 
the United Republic of Tanzania, Zambia and Zimbabwe moved in another direction of their potential for agricultural development and uncovers the diversity in their profiles in many crops and associated value chains. ${ }^{50}$ The realisation brought about a quickened growth rate in the late $20^{\text {th }}$ century to the $21^{\text {st }}$ century with "GDP growth rates as the highest in the world with 9.9 per cent and 10.3 per cent up from 6 per cent in the 1970s". ${ }^{51}$ The Republic of Korea's growth approach utilises the world market's opportunities by the mobilisation of local investors and institutions. ${ }^{52,53}$ For example;

Asia has become a global center of manufacturing during the last quarter of the 20th century. At first, Japan was the only major exporter of manufactured goods in Asia. As the yen rapidly appreciated after the Plaza Accord in 1985, newly industrialized economies (NIES) such as Korea, Taiwan, Hong Kong, and Singapore emerged as exporters of relatively standardized goods. ${ }^{54}$

Until recently, the activities of international development organisations in developing countries were widely considered to be peripheral to the mainstream efforts of governments and agencies to resolve the problems of world poverty. This is premised on a situation that poor countries have a special feature that stands to establish different role for the government as it particularly affects economic growth. ${ }^{55,56}$ This is because poverty according to development research remains the fundamental challenge for the world economic system..$^{57}$

Since the early $19^{\text {th }}$ century, livelihoods in modern societies have been built on the fundamentals of the economy through industrial revolution. ${ }^{58,59}$ Such a radical transformation of industrial structure could be regarded as an engine and alternative route of any nation's high sustained economic

\footnotetext{
${ }^{50}$ World Bank World Bank. State and Trends of Carbon Pricing 2014. World Bank Publications, 2014.

51 Okoli, F. C. Politics of Development and underdevelopment: Theories of development. Enugu: Ingenious Creations Services Ltd, 2007.

${ }^{52}$ Salami, Reza, and Javad Soltanzadeh. "Comparative analysis for science, technology and innovation policy; Lessons learned from some selected countries (Brazil, India, China, South Korea and South Africa) for other LdCs like Iran." Journal of technology management \& innovation 7, no. 1 (2012): 211-227.

${ }^{53}$ Fujimoto, Takahiro. "Architecture-based comparative advantage in Japan and Asia." In Manufacturing Systems and Technologies for the New Frontier, pp. 7-10. Springer, London, 2008.

${ }_{54}$ Adamolekun, Ladipo. Public administration: A Nigerian and comparative perspective. Addison-Wesley Longman Ltd, 1983.

55 Abor, Joshua, and Peter Quartey. "Issues in SME development in Ghana and South Africa." International research journal of finance and economics 39, no. 6 (2010): 215-228.

${ }^{56}$ Burns, T. R. Sustainable development, (2013). Retrieved from www. editorial arrangement of sociopedia.isa on $4 / 5 / 18$

57 UNIDO, A selection of UNIDO field projects, (2013). Retrieved from https://www.unido.org/who-weare/unido-worldwidelafrica/selected-projectson 24/8/18.

58 Otsuka, Keijiro, and Tetsushi Sonobe. "Strategy for cluster-based industrial development in developing countries." Industrialization of Developing Countries (2006): 67.

59 Yong, L. Statement of the Director General United Nations Industrial Development Organisation, (2013) Retrieved from https://www.unido.org on 14/6/2018.
} 
development. ${ }^{60,61}$ This is consequent upon the fact that industrialisation has facilitated the lifting of hundreds of millions of people around the globe out of poverty over the last 200 years with employment generation which multiply in high standard of living and rural development. ${ }^{62,63,64}$ There is the fact that the nations that have experienced steady economic growth with the aid of industrial development, international related-oriented services and trade were altogether the ones that struggled to reduce poverty most effectively. ${ }^{65,66}$ Subsequently:

Industrialisation is...part and parcel of the complex modernisation process. With industrialisation, socio-economic development is attributed to great advancement in technological innovation. This technological innovation that necessitates industrialisation rests in the area of large-scale energy production as well as metallurgy production. From a broad perspective, industrialisation is the organisation of an economy in a manner that allows for large-scale manufacturing. ${ }^{67}$

The designs of imperial and colonial power which governed the world in the $19^{\text {th }}$ and early $20^{\text {th }}$ centuries made little provision for economic and social progress in what is referred to as the developing world. ${ }^{68}$ Colonial regions as designed by the Europeans were only made to be suppliers of foreign industrial raw materials, cheap labour and to lay the foundation for their industrial take-off in (the North America or Western Europe) mid-19 century. ${ }^{69,70,71,72,73}$ Thus, wealth has not been equally distributed throughout the world. This resulted in the considerable differences that exist between and within countries, societies and regions and it has made development

\footnotetext{
${ }^{60} \mathrm{Kim}$, Joon-Kyung, Sang Dal Shim, and Jun-Il Kim. "The role of the government in promoting industrialization and human capital accumulation in Korea." In Growth Theories in Light of the East Asian Experience, pp. 181-200. University of Chicago Press, 1995.

${ }_{61}$ Imhanlahimhin, J. E. Development administration in the less developed countries. Apapa-Lagos: Amfitop Books, 2000.

${ }^{62}$ Otite, U. Poverty in Nigeria: Ibadan. The Noble Publishers, 1990.

63 Kaygusuz, K. Energy services and energy poverty for sustainable rural development. Renewable and Sustainable Energy Reviews, 15 no 2 (2011): 936-947.

64 Akwara, Azalahu F., Ngozi F. Akwara, John Enwuchola, Morufu Adekunle, and Joseph E. Udaw. "Unemployment and poverty: Implications for national security and good governance in Nigeria." International Journal of Public Administration and Management Research 2, no. 1 (2013): 1-11.

${ }^{65}$ Riddell, Roger C., and Mark Robinson. Non-governmental organizations and rural poverty alleviation. Oxford University Press, 1995.

66 Yong, L. Statement of the Director General United Nations Industrial Development Organisation, (2013). Retrieved from https://www.unido.org on 14/6/2018.

${ }^{67}$ Statement of the Director General United Nations Industrial Development Organisation, (2013). Retrieved from https://www.unido.org on 14/6/2018.

68 Harris, Jonathan M. "Basic principles of sustainable development." Dimensions of Sustainable Developmnet (2000): 21-41.

69 Ananaba, Wogu. The trade union movement in Nigeria. Hurst, 1969.

${ }^{70}$ Rodney, Walter. "How Europe Underdeveloped Africa, Dar es Salaam." Tanzania Publishing House, 1972.

${ }^{71}$ Ake, Claude. A political economy of Africa. Vol. 4. London: Longman, 1981.

72 Acemoglu, Daron, and James A. Robinson. "The origins of power, prosperity, and poverty: Why nations fail." Crown Business, New York NY, 2012.

${ }^{73}$ Ofor, O. Industrialisation: Key to national economic independence. A public lecture delivered in the Veritas University, Abuja, (2018). Retrieved from http://veritas.edu.ng/bulletin/prof_ofor_lecture on 6/6/18
} 
and growth to elude important segments of the. ${ }^{74,75}$ Emphatically, Africa is placed as:

...part of the world with the institutions least able to take advantage of the opportunities made available by the Industrial Revolution. For at least the last one thousand years, outside of small pockets and during limited periods of time, Africa has lagged behind the rest of the world in terms of technology, political development, and prosperity. ${ }^{76}$

On the other hand, industrialisation represents a development that involves economic and social change and the advantage of this process is "the transformation of a society from the pre-industrial stage into industrial stage."77 Japanese manufacturing firms benefited by shifting their production facilities mainly to ASEAN countries and in the 1990s, China developed as a main exporter of certain labour-intensive goods. ${ }^{78}$

Nonetheless, UNIDO was created in 1966 and charged with the primary responsibility of promoting sustainable industrial development throughout the developing world in collaboration with its 171 Member States. It became a specialized agency with a well-defined organisational structure of the United Nations in 1985 and its headquarters is in Vienna, and it is represented in 35 developing countries through its field offices. ${ }^{79}$ The organisation has assisted countries with transiting economies in the struggle against global economic marginalisation. Illustratively, sub-Saharan Africa ended the $20^{\text {th }}$ century as the most aid-dependent and heavily indebted region in the world and that its economic history over the past decades can be interpreted as a process of marginalisation. ${ }^{80}$ In strong terms, industrial revolution:

...gave birth to a large middle class, political modernization through the extension of the franchise, the growth of political parties, social development, the rule of law, specialization and differentiation in different sectors of the economy (both public and private), efficiency and

\footnotetext{
${ }^{74}$ Imhanlahimhin, J. E. Development administration in the less developed countries. Apapa-Lagos: Amfitop Books, 2000

${ }_{5}^{5}$ Yong, L. Statement of the Director General United Nations Industrial Development Organisation, (2013). Retrieved from https://www.unido.org on 14/6/2018

${ }^{76}$ Acemoglu, Daron, and James A. Robinson. "The origins of power, prosperity, and poverty: Why nations fail." Crown Business, New York NY, 2012.

77 Industrialisation: A tool for social change. Accessed from https://www.ukessays.com/services on 23 $16 / 2019$

${ }^{78}$ Fujimoto, Takahiro. "Architecture-based comparative advantage in Japan and Asia." In Manufacturing Systems and Technologies for the New Frontier, pp. 7-10. Springer, London, 2008.

${ }_{79}$ UNIDO, Inclusive and sustainable industrial development in Africa Region. Vienna-Austria: Vienna International Centre, (2015).

${ }^{80} \mathrm{Gelb}$, A. "From adjustment to sustainable growth? Sub-Saharan Africa at the turn of the century." In Paper delivered at the 1999 Annual TIPS Forum, Glenburn Lodge, Muldersdrift. 1999.
} 
effectiveness, administrative competence, effective political control over administration, and the general growth and development of the economy. ${ }^{81}$

The findings from Asian Development Bank (ADB) studies have shown that the current development processes and strategies constructed an original economic situations and opportunities that are uneven. ${ }^{82}$ Consequently, the More Developed Countries (MDCs) emerged from vibrant economic sector and with the industrial revolution. For that reason, "UNIDO focuses its technical cooperation activities on its main thematic priority of industrializing the world" in line with the current Sustainable Development Goals (SDGs).

Though the research is a qualitative one, it utilised secondary data collection method. Thematic approach was adopted in the discussion of issues raised. Basically, analysis occurs both within the descriptive and inferential analysis and the qualitative description with thematic text are often between the two approaches. ${ }^{83}$ We thematically described the synthesis of UNIDO support and the development of industries in Nigeria with the review of several literature. The soundness and dependability of this study is manifested in the adoption and application of the "Top-Down Theory."

The "Top-Down" policy implementation theory is adopted for this study. The first attempt at presenting the model was accomplished by Pressman \& Wildavsky, Van Meter \& Van Horn, Bardach, and Gholipour, Jandaghi \& Fallah $^{84,85,86,87}$. It was popularised in the 1980s by Sabatier, Mazmanian, Nakamura \& Smallwood, and Edwards. These scholars "emphasized the importance of policy design that provided explicit policy directives, clear statements of administrative responsibilities, and more direct actions with fewer veto points."

According to them, the model presents the most vital role in implementation of public policies by identifying the variables that affect plans. These are nature, structural and background variables. As Edwards note, four reasons which include resources, bureaucratic structure, communication, and enforcement trends influence policy implementation. 88 The model represents a command and control system from the government of the day to the project.

${ }^{81}$ Imhanlahimhin, J. E. Development administration in the less developed countries. Apapa-Lagos: Amfitop Books, 2000

${ }^{82}$ Rauniyar, Ganesh, and Ravi Kanbur. "Inclusive growth and inclusive development: a review and synthesis of Asian Development Bank literature." Journal of the Asia Pacific Economy 15, no. 4 (2010): 455-469.

${ }_{83}$ Creswell, J. W., \& Creswell, J. Research design (2003) (pp. 155-179). Thousand Oaks, CA: Sage publications.

${ }^{84}$ Pressman, Jeffrey, and Aaron Wildavsky. "Implementation. Berkely." 1973.

85 Van Meter, Donald S., and Carl E. Van Horn. "The policy implementation process: A conceptual framework." Administration \& Society 6, no. 4 (1975): 445-488.

${ }_{86}$ Bardach, Eugene. "The implementation game: What happens after a bill becomes a law." (1977).

87 Gholipour, Rahmatollah, Gholamrea Jandaghi, and Mohammad Reza Fallah. "Introducing a model for implementation of industrial policies: A case study in Qom Province, Iran." American Journal of Economics (2012): 1-5.

${ }_{88}$ Introducing a model for implementation of industrial policies: A Case Study in Qom Province, Iran. American Journal of Economics, Special Issue, (2012): 1-5. 
This is because; development process itself is dictated by factors like innovation, creativity and flexibility which reorganisation becomes very important for achievement of genuine results of any developmental efforts. Therefore, the UNIDO support is very functional to successful development of industries in developing economies at large and Nigeria in particular. The top-down theory is applied in this study to defend the fact that inclusive industrialisation is formulated on the one hand at the - top level organisation of UNIDO and while in another development, its execution and assessment is carried out at the national level of member states respectively.

This however, applies in greater or lesser extent to all programmatic fields of activity contains a number of individual programmes, which are implemented in a holistic manner to achieve effective outcomes and impacts through UNIDO's four enabling functions that entail technical cooperation; analytical and research and policy advisory services; normative, standards and quality-related activities; and partnerships convention for knowledge, networking, transfer and industrial cooperation. Therefore, the top down model sees the starting point of implementation as this decision and identifies the central actors as most influential in producing the desired effects of the decision. ${ }^{89,90,91}$

\section{Assessment of findings: UNIDO has not made a considerable impact on Nigerian industrialisation}

Industrial revolution that brought a dramatic breakthrough in England around 1750 has still not extended to Africa consequent upon the fact that the whole regions in the continent has been ravaged by a standing vicious circle of the persistence and re-creation of empty economic and political frameworks. In the same vein, there was a financial assistance of $€ 12$ million from the European Union (EU) and UNIDO which was meant to assist the Federal Government of Nigeria in implementing its strategic economic structures like Vision 20:2020, National Economic Empowerment and Development Strategy (NEEDS), Transformation Agenda, and Economic Recovery Growth Plan (ERGP) of the President Buhari's administration with the mandate of coining policy structures to develop competitiveness, economic expansion and diversification in the non-oil-related industries. However, UNIDO stated that "Nigeria lacks an internationally recognised National Quality Infrastructure (NQI) with the capacity to ensure

\footnotetext{
89 Van Meter, Donald S., and Carl E. Van Horn. "The policy implementation process: A conceptual framework." Administration \& Society 6, no. 4 (1975): 445-488.

90 Mazmanian, Daniel A., and Paul A. Sabatier. "Implementation and Public Policy (Glenview, IL: Scott, Foresman)." Mazmanian Implementation and Public Policy, 1983

${ }_{91}$ Implementation and public policy (rev. ed.). Latham, MD: University Press of America, 1989.
} 
safety, integrity and marketability of goods and services, and the removal of technical barriers to local, regional and international trade."

Remarkably, despite UNIDO financial and policy support, local manufacturing sector in Nigeria is technologically far behind China, India, Taiwan, Indonesia, Korea, Brazil, and Mexico basically because the country has not enjoyed any foreign policy support in her quest for accelerated industrial development. The sector added only 4.2\% to the GDP in 2010 and the progression since then is $7.6 \%$ as Purchasing Managers Index (PMI) indicated (FGN, 2015). Nigeria had only 5,300 miles of accessed roads and estimated 1,770 miles of railway track at the time of independence which is not being regularly extended, coupled with the unpredictable weather conditions. ${ }^{92}$ Presently, steamer traffic on the inland waterways structure is experienced at flood time in Nigeria because the country does not have a first-class natural port except Apapa and Port Harcourt - the main reason for Apapa gridlock which slows down the commercial activities at the port and loss of lives.

As a result of this, many industrial estates and manufacturing plants in Aba - Abia State; Nnewi - Anambra State; Sharada - Kano State; Ogba - Lagos State; Sango-Ota, Ifo and Shagamu - Ogun State to mention few have turned into deserts and converted to worship centres particularly in Lagos. PAN plant in Kaduna [Northern Nigeria] has also crumpled. A few key industries, such as beverages, textiles, cement and tobacco are now those that are keeping the sector floating, but even these operated at under half of their capacity due to importation.

The recent GDP report released by the Nigerian Bureau of Statistics (NBS) revealed that the real GDP of the manufacturing sector contracted by $-2.75 \% .^{93}$ This contraction in the real GDP of the Manufacturing sector, leaves the sector in a vulnerable position. As NBS noted, the sector's computation grew by $0.77 \%$ in 2019 and $2.09 \%$ in 2018 . It is essential to understand that in nominal terms, without factoring in the change in prices in 2020, the Nominal GDP of the sector recorded a growth rate of $16.44 \%$ at the end of the year, compared to $34.73 \%$ in $2019 .{ }^{94}$ It is succinctly put that: $: 5$

i. At the end of the fourth quarter of 2020: the manufacturing sector's Real GDP contracted by $-1.51 \%$ (year-on-year). This is lower than the corresponding quarter of 2019 and the preceding quarter by $-2.75 \%$ points and $-0.01 \%$ points respectively.

\footnotetext{
${ }^{92}$ Williams, Phyllis H. "The industrialization of Nigeria." In Proceedings of the Oklahoma Academy of Science, vol. 45, pp. 215-218. 1965.

${ }^{93}$ The Nigerian Bureau of Statistics (NBS). Nigerian manufacturing sector data, 2020.

94 Ajayi Omokolade, Nigeria's manufacturing sector contracts by $2.75 \%$ in 2020. Accessed from https://nairametrics.com/2021/02/18/nigerias-manufacturing-sector-contracts-by-2-75-in-2020/
} 
ii. The growth rate of the sector, on a quarter-on-quarter basis, stood at $5.60 \%$.

iii. The sector's GDP growth at the end of the fourth quarter of 2020 was recorded at $24.60 \%$ (year-on-year), this is $-1.69 \%$ points lower than $26.29 \%$ recorded in the corresponding period of 2019 but $11.06 \%$ points higher than the preceding quarter $(13.54 \%)$.

iv. In nominal terms, quarter on quarter growth of the sector was recorded at $5.78 \%$

v. The Real contribution of the sector to the Nation's GDP in the fourth quarter of 2020 was $8.60 \%$, which is lower than the $8.74 \%$ recorded in the fourth quarter of 2019 and the $8.93 \%$ recorded in the third quarter of 2020 . vi. At the end of 2020, the annual contribution of the Manufacturing sector to Nigeria's GDP stood at $8.99 \%$.

However, UNIDO's involvement plans spanned through "industrial governance, research and statistics; Micro, Small and Medium Enterprises (MSMEs) development; Special Economic Zones (SEZs), industrial parks and private sector development; innovation, science and technology management; agro-industry and agri-business development; minerals and metals development; trade capacity building; renewable energy development, and environmental management;" and Information Technology initiatives for Youth, digital technology that would support Nigeria build up and grow its industrial sector at an estimated cost of $\$ 50$ million. Though these involvement designs are robust, no definite attempt is vigorously committed to supporting the significant efforts of Nigerian government to ban importation (the hydra-headed challenge facing local industries), boost the national productivity and achievement of sustainable industrialisation through value addition, establishment of economic zones and permanent diversification of economic and productive activities for development and poverty eradication.

Nevertheless, it is claimed that during the first 15 years of the second millennium, the global economy grew at an average rate of $2.7 \%$ and the number of people living with less than $\$ 1.25$ dropped from $43 \%$ to $23 \% .^{96}$ As it can be observed in Nigeria - the most populous, import-based and monolithic economic country in Africa, the account is in severe contrast. This can be buttressed by the fact that even though the country is rich and naturally endowed with both material and human resources, seven (7) amongst every ten (10) Nigerians live on less than $\$ 1$ a day. ${ }^{97,98,99}$ In addition,

\footnotetext{
${ }^{96}$ F. Haidara, F. UNIDO's commitment to ensure that "No One is Left Behind," (2017). Retrieved from https://isid.unido.org/speakers-corner.htmlon 23/6/18

97 IMF, Nigeria: poverty reduction strategy paper - National Economic Empowerment and Development Strategy. Washington, D.C: Monetary Fund Country Report No. 05 (2005): 433

98 Okonjo-Iweala, Ngozi. Reforming the unreformable: Lessons from Nigeria. Mit Press, 2014.

${ }^{99}$ C. Ezedinma, Path to industrial growth, by UNIDO. The Guardian Business News, November, $2016,25$.
} 
although nearly all African countries witnessed impressive growth rates during the past 10 years, the impacts on poverty reduction have been unsatisfactory. The effect of this situation is pictured by the IMF thus, "at 5.3 percent, the rate of urbanization in Nigeria is among the highest in the world. Since manufacturing is stagnant, there are few jobs for the growing urban population, and urban unemployment is currently estimated at 10.8 percent." The country is in the group of nations that has maximum city population spread and growth rates globally. ${ }^{100}$ This could also be a manifestation of the high levels of regional inequalities, declining agricultural productivity and manufacturing stagnation which create negative impacts on overall development. Presently, production is mainly situated in Lagos and its periphery, and to a smaller degree some other commercial centres like Kaduna, Kano, Aba, Onitsha, Sango-Ota, Shagamu.

Categorically, industries that are established in developing countries hardly produce exported goods and at present, manufacturing activities have declined. It is observed that 800 and industries and 272 firms have crumpled from 2009-2016 along 20\% capacity operation. Nigerian Stock Exchange (NSE) also delisted 60 major companies in 2012 due to poor performance of their stock (see lists in Appendix). Also, Nigerian Textiles Mills with over 180 factories have turned into bush across the country. The Mills are essential for industrial clusters because there are clear advantages on their existence, particularly in developing countries where markets are less developed. Thus;

The superficial character of Nigeria's technological facility equally halted the economy from stirring ahead of the basic stages of the ambitious industrial development programmes outlined in the Second $(1970-74)$ and Fourth (1981 - 85) National Development Plans respectively. These are plans in areas like fertiliser, cement, salt, sugar, pulp and paper, iron and steel, which are indeed operating at a low level or are non-existent. ${ }^{101}$

To a reasonable extent the policy framework has been provided by UNIDO, but the technological expertise and manpower, political will, and industries that will turn around the available raw materials are lacking. There is high level of environmental pollution in the Niger Delta Region of Nigeria over the years due to the activities of foreign oil companies and the impact of UNIDO is not felt as it is a continuous challenge for successive governments in Nigeria. In another perspective, UNIDO's strategic framework is among the transferred planning technique which hardly succeeds in Nigeria due to the reasons of mismanagement resources directly related to Nigerian situation and environment, heavy reliance on foreign

\footnotetext{
${ }^{100}$ Paul, Salisu Ojonemi. "National Urban Development Policy and the Unanswered Development Question of Slum in Nigeria." International Journal of Public Policy and Administration Research 6, no. 2 (2019): 102-115.

${ }_{101}$ Paul, Salisu Ojonemi and Chikelue Ofuebe. "The inclusive and sustainable industrial development policy: which way for Nigeria?" Scientific Papers of the Legislation Institute of the Verkhovna Rada of Ukraine 4 (2020) $157-169$.
} 
experts and absence of local economist in the planning process. For the time being, Nigeria is consuming finished products including some raw materials. Also, in infrastructural construction and maintenance for instance, experts are recruited from other countries. Following these developments, it can be advanced that the UNIDO supports have not significantly impacted industrialisation in Nigeria.

\section{Conclusion}

It is indispensable to note that industrial development is a fundamental element in the measurement of contemporary economic value of Social Progress Index (SPI) and GDP because it plays a pivotal role in poverty alleviation, social stability and productive employment generation through capacity building. Hence, the derivatives of the communiquй of World Summit for Social Development and the outcome of the $24^{\text {th }}$ special session of the United Nations General Assembly in 2013 out which the UNIDO aggressive and inclusive industrialisation was borne can be achieved. Nevertheless, it has emphasised the adoption of Top-Down Approach in the distribution of responsibilities for establishing productive job opportunities through which the marginalized member states can be stakeholders in the manufacturing process. Summarily, we recommend the following necessary actions.

i. Creation of support programmes for Small and Medium-size Enterprises (SMEs) being major channels of entrepreneurship development, employment creation, innovation and socio-economic sustainable growth.

ii. Development of investment and technological promotion environment, improvement of industrial domination, official and regulatory framework, data and critical infrastructure.

iii. Sustaining the establishments of a wide-range business-oriented institutions and organisations for the provision of collective and targeted services for other enterprises mainly in traditional sectors such as food, textiles, wood, leather, and agro-mechanism), but also in intensive economic segments like electronics and biotechnology.

Appendix 1: Official List of Delisted Companies in Nigeria

\begin{tabular}{|c|l|c|l|}
\hline S/N & \multicolumn{1}{|c|}{ Company } & Date delisted & \multicolumn{1}{|c|}{ Reason for delisting } \\
\hline 1 & IMPRESIT BAKOLORI PLC & 2002 & Voluntary \\
\hline 2 & DUMEZ NIGERIA PLC & 2002 & Regulatory: NSE \\
\hline 3 & CFOA NIGERIA PLC & 2007 & Voluntary \\
\hline 4 & ACEN INSURANCE PLC & 2008 & Regulatory: NAICOM \\
\hline 5 & ATLAS NIGERIA PLC & 2008 & Regulatory: NSE \\
\hline
\end{tabular}


Continuation of the application 1

\begin{tabular}{|c|l|c|l|}
\hline S/N & \multicolumn{1}{|c|}{ Company } & Date delisted & \multicolumn{1}{|c|}{ Reason for delisting } \\
\hline 6 & CERAMICS MFG. COY. PLC & 2008 & Regulatory: NSE \\
\hline 7 & AMICABLE INSURANCE PLC & 2008 & Regulatory: NAICOM \\
\hline 8 & BAICO INSURANCE PLC & 2008 & Regulatory: NAICOM \\
\hline 9 & BEVERAGES (WA) NIG. PLC & 2008 & Regulatory: NSE \\
\hline 10 & ENPEE PLC & 2008 & Regulatory: NSE \\
\hline 11 & TATE INDUSTRIES PLC & 2008 & Regulatory: NSE \\
\hline 12 & MAUREEN LAB. PLC & 2008 & Regulatory: NSE \\
\hline 13 & RIETZCOT NIGERIA PLC & 2008 & Regulatory: NSE \\
\hline 14 & INTRA MOTORS NIG. PLC & 2008 & Regulatory: NSE \\
\hline 15 & AVIATION DEV. COY. PLC & 2008 & Regulatory: NAICOM \\
\hline 16 & GROMMAC INDUSTRIES PLC & 2008 & Regulatory: NSE \\
\hline 17 & ONWUKA HI-TEK. PLC & 2008 & Regulatory: NSE \\
\hline 18 & NIGERIAN LAMPS PLC & 2008 & Regulatory: NSE \\
\hline 19 & NIGERIAN YEAST \& ALCAHOL & 2008 & Regulatory: NSE \\
\hline 20 & SECURITY ASS. PLC & 2008 & Regulatory: NAICOM \\
\hline 21 & SUN INSURANCE PLC & 2008 & Regulatory: NAICOM \\
\hline 22 & NIGERIAN TEXT. MILLS PLC & 2008 & Voluntary \\
\hline 23 & FOOTWEAR MFG. PLC & 2009 & Regulatory: NSE \\
\hline 24 & FERDINAND OIL MILLS PLC & 2009 & Regulatory: NSE \\
\hline 25 & CHRISTLIEB PLC & 2009 & Regulatory: NSE \\
\hline 26 & BCN PLC & 2009 & Regulatory: NSE \\
\hline 27 & LIZ-OLOFIN \& COY. PLC & 2009 & Regulatory: NSE \\
\hline 28 & OLUWA GLASS COY. PLC & 2009 & Regulatory: NSE \\
\hline 29 & ASABA TEXTILE MILLS PLC & 2009 & Regulatory: NSE \\
\hline 30 & ABOSELDEHYDE LAB. PLC & 2009 & Regulatory: NSE \\
\hline 31 & EPIC DYNAMIC PLC & 2009 & Regulatory: NSE \\
\hline 32 & FADMAD PLC & 2009 & Regulatory: NSE \\
\hline 33 & ABA TEXTILE MILLS PLC & 2009 & Regulatory: NSE \\
\hline 34 & AFPRINT PLC & 2010 & Regulatory: NSE \\
\hline 35 & INCAR PLC & 2010 & Voluntary \\
\hline 36 & NIGERCEM PLC & Regulatory: NSE \\
\hline 37 & DAILY TIMES PLC & Regulatory: NSE \\
\hline 38 & ALBARKA AIRLINE PLC & Regulatory: NSE \\
\hline 39 & FOREMOST DAIRIES PLC & Regulatory: NSE \\
\hline
\end{tabular}


THE UNITED NATIONS INDUSTRIAL DEVELOPMENT ORGANIZATION'S ROLE IN MODERN INDUSTRIALIZATION OF NIGERIA

End of application 1

\begin{tabular}{|c|c|c|c|}
\hline $\mathbf{S} / \mathbf{N}$ & Company & Date delisted & Reason for delisting \\
\hline 40 & WIGGINS TEAPE NIG. LC & 2011 & Regulatory: NSE \\
\hline 41 & OKITIPUPA OIL PALM PLC & 2011 & Regulatory: NSE \\
\hline 42 & FIRST CAP. INV. \& TRUST PLC & 2011 & Regulatory: NSE \\
\hline 43 & FLEXIBLE PACKAGING PLC & 2011 & Regulatory: NSE \\
\hline 44 & NEWPAK PLC & 2011 & Regulatory: NSE \\
\hline 45 & KRABO NIGERIA PLC & 2011 & Regulatory: NSE \\
\hline 46 & TROPICAL PETRO. PLC & 2011 & Regulatory: NSE \\
\hline 47 & NIGERIAN BOTTLING COY PLC & 2011 & Voluntary \\
\hline 48 & NAMPAK PLC & 2011 & Voluntary \\
\hline 49 & UNITED NIG. TEX. PLC & 2011 & Voluntary \\
\hline 50 & BANK PHB PLC & 2011 & Nationalised: CBN \\
\hline 51 & AFRIBANK PLC & 2011 & Nationalised: CBN \\
\hline 52 & SPRING BANK PLC & 2011 & Nationalised: CBN \\
\hline 53 & INTERCONTINENTAL BANK PLC & 2011 & $\begin{array}{l}\text { Merged with Access Bank } \\
\text { Plc. }\end{array}$ \\
\hline 54 & OCEANIC BANK PLC & 2011 & Merged with ETI \\
\hline 55 & FINBANK PLC & 2011 & Merged with FCMB Plc. \\
\hline 56 & ECOBANK PLC & 2011 & $\begin{array}{l}\text { Absorbed by ETI: Now } \\
\text { Ecobank Nigeria Ltd }\end{array}$ \\
\hline 57 & ABPLAST PLC & 2012 & Regulatory: NSE \\
\hline 58 & UDEOFOSIN GARMENT PLC & 2012 & Regulatory: NSE \\
\hline 59 & $\begin{array}{l}\text { HALLMARK PAPER PRODUCT } \\
\text { PLC }\end{array}$ & 2012 & Regulatory: NSE \\
\hline 60 & BACGO BAG PLC & April 11, 2013 & Merged with Flour Mills Plc \\
\hline 61 & CRUSADER NIGERIA PLC & May 13, 2013 & $\begin{array}{l}\text { Merged with Custodian \& } \\
\text { Allied Insurance Plc. }\end{array}$ \\
\hline 62 & WEST AFRICAN ALUMINIUM PLC & June 3, 2013 & Regulatory: NSE \\
\hline 63 & NIGERIAN WIRE INDUSTRY PLC & Jun2 3, 2013 & Regulatory: NSE \\
\hline
\end{tabular}

Source: Nigerian Stock Exchange (2014).

\section{References}

1. Abor, Joshua, and Peter Quartey. "Issues in SME development in Ghana and South Africa." International research journal of finance and economics 39, no. 6 (2010): 215-228.

2. Acemoglu, Daron, and James A. Robinson. "The origins of power, prosperity, and poverty: Why nations fail." Crown Business, New York NY, 2012. 
3. Adamolekun, Ladipo. Public administration: A Nigerian and comparative perspective. Addison-Wesley Longman Ltd, 1983.

4. Agba, A. M. O., and Emmanuel Odu. "Globalization and the challenge of industrialization in developing nations: The Nigeria experience." IOSR Journal of Humanities and Social Science 12, no. 4 (2013): 41-47.

Ajayi Omokolade, Nigeria's manufacturing sector contracts by $2.75 \%$ in 2020 . URL: https://nairametrics.com/2021/02/18/nigerias-manufacturing-sectorcontracts-by-2-75-in-2020/

6. Ajayi, Dare Dickson. "Recent trends and patterns in Nigeria's industrial development." Africa Development 32, no. 2 (2007): 139-155.

7. Ake, Claude. A political economy of Africa. Vol. 4. London: Longman, 1981.

8. Akpoti, N. Ajaokuta Steel Company, House of Reps and the acquisition plot. The Sahara Reporters, New York. March 26, (2018).

9. Akwara, Azalahu F., Ngozi F. Akwara, John Enwuchola, Morufu Adekunle, and Joseph E. Udaw. "Unemployment and poverty: Implications for national security and good governance in Nigeria." International Journal of Public Administration and Management Research 2, no. 1 (2013): 1-11.

10. Ananaba, Wogu. The trade union movement in Nigeria. Hurst, 1969.

11. Anger, Barnes. "Poverty eradication, millennium development goals and sustainable development in Nigeria." Journal of sustainable development 3, no. 4 (2010): 138-144.

12. Asaju, Kayode. "Industrialization: The Key to Nigerian's Developmental Questions." American Journal of Social Sciences 3, no. 3 (2015): 62-68.

13. Bardach, Eugene. "The implementation game: What happens after a bill becomes a law." (1977).

14. Bawa-Bwari, A. FG spent \$10bn on Ajaokuta Steel Company. The Punch Newspaper, August, 2016, 19.

15. Bijan, Zheng. "China's peaceful rise to great-power status." Foreign Affairs. 84 (2005): 18.

16. Burns, T. R. Sustainable development, (2013). Retrieved from $w W W$ editorial arrangement of sociopedia.isa on $4 / 5 / 18$

17. Calhoun, Craig, Georgi Derluguian, and Georgi M. Derluguian, eds. The deepening crisis: governance challenges after neoliberalism. NYU Press, 2011.

18. Cheng, S. K., Q. W. Min, and L. F. Li. "Research and theories in sustainable development in china, "Social and Economic Development-Volume VIII(2010): 208. Retrieved from http: / / Www.eolss.net/Sample-Chapters $/ C 16 / E 1-54-44 . p d f$, on $10 / 4 / 18$

19. Creswell, J. W., \& Creswell, J. Research design (2003) (pp. 155-179). Thousand Oaks, CA: Sage publications.

20. Dankumo, A., Joshua Sunday Riti, and Bashir Saka Ayeni. "Contribution of Agricultural and Industrial Sectors to the Development of Nigerian Economy from 1995 to 2012." International Journal of Business, Management and Allied Science 2 (2015): 2128-2135.

21. Encyclopedia of Sociology, "Dictionary definition of Industrialization in Less Developed Countries." (2011). Retrieved from encyclopedia.com, free online dictionary on $23 / 3 / 18$. 
22. Ezedinma, C. Path to industrial growth, by UNIDO. The Guardian Business News, November, 2016, 25.

23. FGN, Public Service Reforms in Nigeria 1999-2014: A comprehensive review. Abuja: The Presidency, 2015.

24. Forrest, Tom, and Tom G. Forrest. The advance of African capital: The growth of Nigerian private enterprise. University of Virginia Press, 1994.

25. Fujimoto, Takahiro. "Architecture-based comparative advantage in Japan and Asia." In Manufacturing Systems and Technologies for the New Frontier, pp. 710. Springer, London, 2008.

26. Gelb, A. "From adjustment to sustainable growth? Sub-Saharan Africa at the turn of the century." In Paper delivered at the 1999 Annual TIPS Forum, Glenburn Lodge, Muldersdrift. 1999.

27. George, S. Uses and abuses of Africa debt. In A. Adedeji (ed.), Africa within the world-beyond dispossession and dependence. London: Zed Books, 1999.

28. Gholipour, Rahmatollah, Gholamrea Jandaghi, and Mohammad Reza Fallah. "Introducing a model for implementation of industrial policies: A case study in Qom Province, Iran." American Journal of Economics (2012): 1-5.

29. Haidara, F. UNIDO's commitment to ensure that "No One is Left Behind,' (2017). Retrieved from https:/ /isid.unido.org/speakers-corner.htmlon $23 / 6 / 18$

30. Harris, Jonathan M. "Basic principles of sustainable development." Dimensions of Sustainable Development (2000): 21-41.

31. Ikpe, Eka. "The Enduring Relevance of the Developmental State Paradigm Across Space and Time: Lessons for Africa on Structural Transformation and Agriculture in Oil-Rich Contexts." Journal of Asian and African Studies53, no. 5 (2018): 764-781. Accessed from https://doi.org/10.1177/0021909617722375 on $10 / 2 / 18$

32. IMF, Nigeria: poverty reduction strategy paper- National Economic Empowerment and Development Strategy. Washington, D.C: Monetary Fund Country Report No. 05 (2005): 433

33. Imhanlahimhin, J. E. Development administration in the less developed countries. Apapa-Lagos: Amfitop Books, 2000.

34. Implementation and public policy (rev. ed.). Latham, MD: University Press of America, 1989.

35. Industrialisation: A tool for social change. Accessed from https: / / WwW.ukessays.com / services on $23 / 6 / 2019$

36. Introducing a model for implementation of industrial policies: A Case Study in Qom Province, Iran. American Journal of Economics, Special Issue, (2012): 1-5

37. Jiboye, Adesoji David. "Urbanization challenges and housing delivery in Nigeria: The need for an effective Policy framework for Sustainable Development." International Review of Social Sciences and Humanities 2, no. 1 (2011): 176-185.

38. Kaplinsky, Raphael. "India's industrial development: an interpretative survey." World Development 25, no. 5 (1997): 681-694.

39. Kaygusuz, K. Energy services and energy poverty for sustainable rural development. Renewable and Sustainable Energy Reviews, 15 no 2 (2011): 936-947. 
40. Kerzner, Harold. Project management: a systems approach to planning, scheduling, and controlling. John Wiley \& Sons, 2017.

41. Kim, Joon-Kyung, Sang Dal Shim, and Jun-Il Kim. "The role of the government in promoting industrialization and human capital accumulation in Korea." In Growth Theories in Light of the East Asian Experience, pp. 181-200. University of Chicago Press, 1995.

42. Klavins, D. "Cultural diplomacy and international relations: New actors; new initiatives; new targets. The ICD Annual Academic Conference on Cultural Diplomacy December, (2015), $15^{\text {th }}-18^{\text {th }}$.

43. Kniivilд, Matleena. "Industrial development and economic growth: Implications for poverty reduction and income inequality." Industrial development for the 21st century: Sustainable development perspectives 1, no. 3 (2007): 295333.

44. Kwanashe, J. D. Sustainable Development Goals: Where is the stand of Africa? Ghanaian Journal of Social Development of Development Research, 3 no 1 (2016): 35-51.

45. Makinde, T. "Essence of bilateral relations in modern diplomacy," (2014), Retrieved from http://media4rural.blogspot.com.ng on $27 / 3 / 2018$.

46. MAN, Nigerian manufacturers lament. Premium Times, January, 2018, 10. Accessed from https: / / WwW.premiumtimesng.comon 13/9/2018.

47. Mayer, Jцrg. Industrialization in developing countries: some evidence from a new economic geography perspective. No. 174: 1-37. United Nations Conference on Trade and Development, 2004.

48. Mazmanian, Daniel A., and Paul A. Sabatier. "Implementation and Public Policy (Glenview, IL: Scott, Foresman)." Mazmanian Implementation and Public Policy, 1983.

49. Metz, Helen Chapin, ed. Nigeria: A country study. Federal Research Division, 1991.

50. Mgbemene, Chigbo A., Chidozie C. Nnaji, and Chekwubechukwu Nwozor. "Industrialization and its backlash: focus on climate change and its consequences." Journal of Environmental Science and Technology9, no. 4 (2016): 301-316.

51. Mirakhor, Abbas, and Hossein Askari. "Institutional Structure of a Sound Economy." In Ideal Islamic Economy, pp. 119-137. Palgrave Macmillan, New York, 2017.

52. NACCIMA, 800 companies shut down in 3 years. The Premium Times, September, 2012, 11. Retrieved from https: WwW.premiumtimesng.com businesson $9 / 8 / 18$.

53. NBS, Nigerian manufacturing sector summary report: 2010-2012. (2015). Retrieved from https: / /WwW.proshareng.com/newson 5/9/18.

54. Obwona, Marios, Isaac Shinyekwa, Julius Kiiza, and Eria Hisali. The evolution of industry in Uganda. No. 2014/021. WIDER Working Paper, 2014.

55. Ofor, O. Industrialisation: Key to national economic independence. A public lecture delivered in the Veritas University, Abuja, (2018). Retrieved from http: / veritas.edu.ng / bulletin / prof ofor_lecture on $6 / 6 / 18$

56. Okoli, F. C. Politics of Devēlopment and underdevelopment: Theories of development. Enugu: Ingenious Creations Services Ltd, 2007. 
57. Okonjo-Iweala, Ngozi. Reforming the unreformable: Lessons from Nigeria. Mit Press, 2014.

58. Olaoye, O. A. "Potentials of the agro industry towards achieving food security in Nigeria and Other Sub-Saharan African Countries." Journal of Food Security 2, no. 1 (2014): 33-41.

59. Olayiwola, Adewale Mukhtar, and Michael Oluwabukunmi Lawal. "Mapping urban growth and its impact on agricultural lands in Abeokuta, Nigeria: 1966-2016." Interdisciplinary Environmental Review 19, no. 3-4 (2018): 289-305.

60. Oluyole, F. Ajaokuta: How Nigeria's largest industrial project failed. Premium Times Daily News, December, (2017), 26.

61. Onah, Fab O. Managing Public Programmes and Projects. Great Ap Express Publishers Limited, 2006.

62. Onah, Roseline, and Jide Ibietan. "Democratic Stability and Regional Economic Integration: The Economic Community of West African States (ECOWAS) Experience." Nigerian Journal of Public Administration and Local Government 14, no. 1 (2009): 17-32.

63. Onimode, Bade. "Unequal Exchange, External Debt and Capacity for Development-Oriented Policies in African Countries." Development Thought, Policy Advice and Economic Development in Africa in the 20th Century: Lessons for the 21st Century: Ibadan: Ibadan (2003): 39 - 56.

64. Onyemelukwe, J. O. C. "Structural and locational characteristics of manufacturing" In J. S. Oguntoyinbo, O., O. Areola \& M. Filani, (eds.), A Geography of Nigerian Development, $2^{\text {nd }}$ edition. Ibadan: Heinemann Educational Books Ltd, (1983): pp. 296-310.

65. Oshewolo, Segun. "Galloping poverty in Nigeria: an appraisal of government interventionist policies." Journal of Sustainable Development in Africa 12, no. 6 (2010): 264-274

66. Otite, U. Poverty in Nigeria: Ibadan. The Noble Publishers, 1990.

67. Otsuka, Keijiro, and Tetsushi Sonobe. "Strategy for cluster-based industrial development in developing countries." Industrialization of Developing Countries (2006): 67

68. Oyeyinka, Oyebanji, and Oluwole Adeloye. "Technological change and project execution in a developing country: evolution of Ajaokuta Steel Plant in Nigeria." Manuscript report/IDRC; 187e(1988).

69. Paul, Salisu Ojonemi and Chikelue Ofuebe. "The inclusive and sustainable industrial development policy: which way for Nigeria?" Scientific Papers of the Legislation Institute of the Verkhovna Rada of Ukraine 4 (2020): 157-169.

70. Paul, Salisu Ojonemi. "National Urban Development Policy and the Unanswered Development Question of Slum in Nigeria." International Journal of Public Policy and Administration Research 6, no. 2 (2019): 102-115.

71. Pressman, Jeffrey, and Aaron Wildavsky. "Implementation. Berkely." 1973.

72. Rauniyar, Ganesh, and Ravi Kanbur. "Inclusive growth and inclusive development: a review and synthesis of Asian Development Bank literature." Journal of the Asia Pacific Economy 15, no. 4 (2010): 455-469.

73. Riddell, Roger C., and Mark Robinson. Non-governmental organizations and rural poverty alleviation. Oxford University Press, 1995. 
74. Rodney, Walter. "How Europe Underdeveloped Africa, Dar es Salaam." Tanzania Publishing House, 1972.

75. Sachs, Jeffrey. The end of poverty: How we can make it happen in our lifetime. Penguin UK, 2005.

76. Salami, Reza, and Javad Soltanzadeh. "Comparative analysis for science, technology and innovation policy; Lessons learned from some selected countries (Brazil, India, China, South Korea and South Africa) for other LdCs like Iran." Journal of technology management \& innovation 7, no. 1 (2012): 211-227.

77. Statement of the Director General United Nations Industrial Development Organisation, (2013). Retrieved from https: / /WWw. unido.org on 14/6/2018.

78. The Nigerian Bureau of Statistics (NBS). Nigerian manufacturing sector data, 2020.

79. Tignor, Robert L. Capitalism and nationalism at the end of empire: state and business in decolonizing Egypt, Nigeria, and Kenya, 1945-1963. Princeton University Press, 2015.

80. Toffler, A. Revolutionary wealth. New Perspectives Quarterly, 30 no 4 (2013): $122-130$.

81. UNIDO, A selection of UNIDO field projects, (2013). Retrieved from https: / /Www.unido.org / who-we-are / unido-worldwide / africa / selectedprojectson $24 / 8 / 18$.

82. UNIDO, Inclusive and sustainable industrial development in Africa Region. Vienna-Austria: Vienna International Centre, (2015).

83. Van Meter, Donald S., and Carl E. Van Horn. "The policy implementation process: A conceptual framework." Administration \& Society6, no. 4 (1975): 445-488.

84. Williams, Phyllis H. "The industrialization of Nigeria." In Proceedings of the Oklahoma Academy of Science, vol. 45, pp. 215-218. 1965.

85. World Bank World Bank. State and Trends of Carbon Pricing 2014. World Bank Publications, 2014.

86. Yong, L. Statement of the Director General United Nations Industrial Development Organisation, (2013). Retrieved from https: / /WWW.unido.org on $14 / 6 / 2018$.

The article was received by the Editorial Board on November 08, 2020. 